\title{
Airway wall remodelling in asthma
}

\author{
Anthony E Redington, Peter H Howarth
}

Although reversibility of airflow obstruction has traditionally formed part of the definition of asthma, ${ }^{1}$ it is apparent that airflow obstruction in asthma is often not completely reversible. A number of investigators have reported that asthmatic patients frequently have persistent lung function abnormalities despite clinical remission..$^{2-6}$ In one study ${ }^{6}$ an attempt was made to maximise lung function by means of bronchodilators and, if necessary, oral corticosteroids in a large group of patients with chronic asthma. Many subjects were nevertheless found to have a degree of irreversible airflow obstruction, irrespective of whether or not they had smoked, and the degree of impairment of lung function correlated with both the duration and severity of the disease. Community studies performed over periods of six years and 18 years in rural communities in America and Western Australia, respectively, ${ }^{78}$ have established that the rate of decline of lung function is greater in asthmatic patients than in non-asthmatic patients. In one of these studies, ${ }^{7}$ for example, the average change in forced expiratory volume in one second $\left(\mathrm{FEV}_{1}\right)$ per year for adult men with asthma was $24 \mathrm{ml}$ compared with $6.3 \mathrm{ml}$ for non-asthmatic men. The rate of decline in $\mathrm{FEV}_{1}$ appears to be most pronounced in those patients with the greatest degrees of airflow obstruction, the so-called "horse-racing" effect. $^{9}$

Taken together these studies indicate that asthma alone is capable of leading to irreversible airflow obstruction. An important factor in this process is believed to be the development of structural changes (remodelling) in the airway wall. The first indications that such changes are a feature of asthma came from post-mortem examinations. In a pioneering study in 1922 Huber and Koessler reviewed the necropsy findings of 21 patients who had died from severe asthma ${ }^{10}$ In addition to partial or total occlusion of the bronchial lumen by mucous plugs and extensive cellular infiltration of the bronchial wall, they reported that a prominent feature in many of the cases examined was the presence of thickening of the airway wall. Detailed measurements of airway wall dimensions were performed in six of these subjects and the results were compared with those from a group of seven non-asthmatic subjects who had died from other causes. In bronchi of external diameter greater than $2 \mathrm{~mm}$ the thickness of the subepithelial layer, the thickness of the muscle layer, and the total wall thickness were all found to be increased in those with asthma.

The use of morphometric techniques to define structural changes in the airway wall has since been greatly extended. Important preliminary observations were made using porcine ${ }^{11}$ guinea pig, ${ }^{12}$ and human ${ }^{13}$ airways. These studies revealed that the internal perimeter and wall area remain relatively constant despite changes in smooth muscle length and lung volume whereas other parameters, such as external perimeter and luminal area, vary markedly. Many of the problems encountered when comparing airways from different sites and from different subjects can therefore be overcome by the use of internal perimeter as a marker of airway size. This approach was first used to quantify airway dimensions in fatal asthma. In a study of post-mortem specimens from 18 asthmatic and 23 non-asthmatic subjects the wall area was found to be significantly increased in the airways of those with asthma. ${ }^{14}$ When membranous airways of internal perimeter $<2 \mathrm{~mm}$ and $\geq 2 \mathrm{~mm}$ and cartilaginous airways of $<10 \mathrm{~mm}$ and $\geq 10 \mathrm{~mm}$ were considered separately, the increase in wall area was found to involve all airway groups. Comparable changes have also been described in resected and post-mortem lung specimens from subjects with non-fatal asthma, although in these cases the differences appeared to involve predominantly the membranous and small cartilaginous airways. $^{1516}$

The contribution of individual components of the airway wall to the total increase in wall area has been analysed. A number of studies have reported that the area of airway smooth muscle is substantially increased in both large $\mathrm{e}^{17-20}$ and small $^{21}$ airways in cases of fatal asthma. Detailed morphometric studies have suggested the existence of two distinct patterns of smooth muscle thickening - those cases where this process is confined to the central airways and those where the changes involve the entire bronchial tree. ${ }^{22}$ It was originally believed that the predominant pathology of the smooth muscle of the airway was that of cellular hyperplasia rather than hypertrophy, as the number of smooth muscle nuclei was reported to be increased approximately threefold. ${ }^{1920}$ However, a more recent study using accurate three-dimensional reconstruction has suggested that, although the increase in airway smooth muscle results from hyperplasia when this process is confined to large airways, hypertrophy predominates when the smaller airways are also involved. ${ }^{23}$ Several investigators have reported that the proportions of bronchial wall area occupied by mucous glands are also increased in fatal asthma, although airway size was not precisely standardised in these early studies. ${ }^{171824}$ In addition, the epithelium, submucosa, vascular compartment, and adventitia have all been shown to contribute to the total increase in wall area. ${ }^{1416}$

Other evidence for the presence of structural abnormalities in the airway wall in patients with asthma derives from radiological studies. Bronchial wall thickening is frequently evident on plain radiographs ${ }^{2526}$ and more detailed information is provided by high resolution computed tomographic (CT) scanning of the lungs. In surveys of patients with asthma of varying severity and aetiology, CT evidence of bronchial wall thickening has been reported in up to $90 \%$ of cases. ${ }^{2526}$ The presence of abnormalities on the CT scan is related to both the duration and clinical severity of the disease. ${ }^{27}$ In another study high resolution CT scanning was used to quantify the thickness of the bronchial wall at the level of the intermediate bronchus in asthmatic subjects, with and without fixed airflow obstruction, as well as in non-asthmatic control subjects. ${ }^{28}$ No difference was detected between the three groups in bronchial wall thickness, expressed in relation to outer diameter, which may reflect the relative insensitivity of CT scanning as a means of quantification. However, in the subjects with fixed airflow obstruction there was a direct correlation between bronchial wall thickness and airway reactivity.

Altered airway structure in asthma may result in altered airway function in a number of ways. An increase in the amount of airway smooth muscle will allow greater shortening in response to a bronchoconstrictor stimulus, and an increase in the adventitial area may lead to un- 
coupling of the distending forces of parenchymal recoil from the forces tending to narrow the airways. ${ }^{29}$ In the morphometric studies described above the degree of smooth muscle shortening required to occlude the lumen was calculated to be lower in the asthmatic airways. ${ }^{14}$ This analysis has been extended using a computer model developed to assess the effects of airway wall thickening and airway smooth muscle shortening on airway resistance. ${ }^{30}$ Using the measurements obtained from post-mortem specimens this model suggests that baseline resistance may be only slightly increased if the airway wall thickens without encroaching on the lumen, but when the smooth muscle shortens even by modest amounts the increase in wall thickness will have an exaggerated effect on the airway lumen and markedly increase airway resistance. ${ }^{31}$ The model also predicts that changes in the smaller conducting airways, which have smooth muscle that completely encircles the airway lumen, will have a much greater effect than similar changes in the more central airways. ${ }^{30}$ Thus, the magnitude of airway wall thickening that is observed in the airways of subjects with asthma may contribute substantially to airway hyperresponsiveness in addition to airflow obstruction.

Tissue remodelling in asthma has received particular attention in relation to one specific component of the airway wall - namely, the specialised region of extracellular matrix beneath the bronchial epithelium. Abnormalities in the basement membrane zone in asthma were first recognised in many early post-mortem studies. ${ }^{1032-35}$ These reports described broadening and hyalinisation of this region, appearances frequently described as basement membrane thickening, with appropriate histological stains suggesting that these changes resulted largely from collagen deposition. Rigid bronchoscopy has provided evidence that similar changes are also present in the airways of living asthmatic subjects ${ }^{2436}$ and subsequently these observations have been confirmed in many studies using fibreoptic bronchoscopy to obtain bronchial biopsy specimens from subjects with mild asthma. ${ }^{37-39}$ The use of electron microscopy to examine the ultrastructure of the basement membrane in asthma has indicated that the organisation of the lamina rara and lamina densa is well preserved but that the lamina reticularis is greatly increased in depth, corresponding to the apparent "basement membrane thickening" described in light microscopic studies. ${ }^{40-42}$ Immunohistochemical analysis has suggested that this thickened layer is largely composed of collagen types III, $\mathrm{V}$ and, to a lesser extent, I and fibronectin. ${ }^{39}$ However, consistent with the electron microscopic findings, the distribution of laminin and collagen IV was reported to be unaltered in asthma. ${ }^{39}$

The appreciation that the principal components of the thickened layer are interstitial collagens suggested that the overlying bronchial epithelial cells are not responsible for its deposition and prompted a search for an appropriate mesenchymal cell population. Using an antibody raised against pericryptal fibroblasts in the gastrointestinal tract, a specialised network of fibroblastic cells with long cytoplasmic extensions was identified beneath the lamina reticularis. ${ }^{43}$ Ultrastructural analysis demonstrated the presence of abundant polyribosomes and occasional parallel arrays of thin filaments consistent with contractile apparatus, indicating that these cells are myofibroblasts. ${ }^{43}$ Although present in normal subjects, the numbers of subepithelial myofibroblasts are increased in asthma and these numbers correlate with the degree of collagen thickness, suggesting that these cells are indeed responsible for the deposition of this layer. ${ }^{43}$

The significance of subepithelial fibrosis in asthma is uncertain. No correlation has been demonstrated between the thickness of this layer, measured in large bronchi, and clinical or physiological indicators of asthma severity. ${ }^{39}$ The myofibroblast numbers do, however, correlate with the duration of asthma ${ }^{43}$ and, in this respect, support the findings of Brown et $a l^{6}$ in their analysis of irreversible airflow obstruction and duration of asthma. The myofibroblast and collagen findings in large airways may act as a marker for remodelling more generally in the airways, particularly in the small airways which represent the predominant site of airflow obstruction in obstructive lung disease. ${ }^{44}$

An important goal of current asthma research is to understand the dysfunction in regulatory mechanisms responsible for remodelling of the airway wall. Many growth factors and other mediators have the potential to be implicated in this process on the basis of their in vitro biological properties. These include transforming growth factor- $\beta,{ }^{45}$ platelet-derived growth factor, ${ }^{46}$ basic fibroblast growth factor, ${ }^{47}$ cytokines such as tumour necrosis factor$\alpha^{48}$ and interleukin $4,{ }^{49}$ the peptide mediator endothelin, ${ }^{50}$ and miscellaneous additional molecules including histamine $^{51}$ and tryptase. ${ }^{52}$ All of these factors are able either to elicit a mitogenic response in fibroblasts and/or airway smooth muscle cells or to promote connective tissue synthesis by these cells. In several cases increased expression of these mediators has been identified in the airways in asthma. ${ }^{53-57}$ However, functional studies will certainly be required before any conclusion can be reached regarding the in vivo importance of an individual mediator.

The clinical relevance of airway wall remodelling in asthma is highlighted by a report from Finland by Haahtela et $a l . .^{58}$ In a comparative longitudinal study of a topical inhaled corticosteroid (budesonide) and a short acting $\beta_{2}$ agonist (terbutaline) they found that the potential to reverse airflow obstruction and measures of bronchial responsiveness was impaired in patients in whom anti-inflammatory therapy was delayed. It is thus possible that these structural changes are more difficult to reverse, once they have occurred, than they are to prevent with prophylactic therapy. The ability of structural changes to develop early in the disease is illustrated by their occurrence in young children ${ }^{42}$ and in occupational asthma following a relatively brief period of exposure to the sensitising agent, ${ }^{59}$ and is also suggested by a report that the greatest loss of lung function in asthma occurs in the early years following diagnosis. ${ }^{60}$ Further studies addressing the effect of treatment on the reversibility and prevention of these structural changes are required as, although inhaled corticosteroids reduce symptoms, improve lung function, modify bronchial hyperresponsiveness, and reduce eosinophilic airway inflammation in asthma, there is only one study suggesting that this mode of treatment is able to reverse airway collagen deposition ${ }^{61}$ with several others reporting no effect. ${ }^{6263}$ Should these studies confirm the relative lack of reversibility of established fibrosis, then this would reinforce the argument for the early introduction of prophylactic medication in patients with mild asthma.

Correspondence to: Dr A E Redington, Room 4H 17-21, Health Sciences Centre, Department of Pathology, McMaster University, 1200 Main Street West, Hamilton, Ontario L8N 3Z5 Canada.

University Medicine,

Southampton General Hospital,

ANTHONY E REDINGTON

Southampton, UK

1 Meneely GR, Renzetti Jr. AD, Steele JD, Wyatt JP, Harris HW. Chronic bronchitis, asthma, and pulmonary emphysema: a statement by the committee on diagnostic standards for nontuberculous respiratory diseases. Am Rev Respir Dis 1962;85:762-8.

2 Beale HD, Fowler WS, Comroe Jr JH. Pulmonary function studies in 20 asthmatic patients in the symptom-free interval. F Allergy 1952;23:1-10.

3 Cade JF, Pain MCF. Pulmonary function during clinical remission of asthma: how reversible is asthma? Aust NZ $\mathcal{F}$ Med 1973;3:545-51. 
4 Palmer KNV, Kelman GR. Pulmonary function in asthmatic patients in remission. BMF 1975;1:485-6.

5 McCarthy DS, Sigurdson M. Lung elastic recoil and reduced airflow in clinically stable asthma. Thorax 1980;35:298-302.

6 Brown PJ, Greville HW, Finucane KE. Asthma and irreversible airflow obstruction. Thorax 1984;39:131-6.

7 Schachter EN, Doyle CA, Beck GJ. A prospective study of asthma in a rural community. Chest 1984;85:623-30.

8 Peat JK, Woolcock AJ, Cullen K. Rate of decline of lung function in subjects with asthma. Eur F Respir Dis 1987;70:171-9.

9 Ulrik CS, Backer V, Dirksen A. A 10 year follow up of 180 adults with bronchial asthma: factors important for the decline in lung function. Thorax 1992;47:14-8.

10 Huber HL, Koessler KK. The pathology of bronchial asthma. Arch Intern Med 1922;30:689-760.

11 James AL, Paré PD, Moreno RH, Hogg JC. Quantitative measurement of smooth muscle shortening in isolated pig trachea. $\mathcal{F}$ Appl Physiol 1987; 63:1360-5.

12 James AL, Paré PD, Hogg JC. Effects of lung volume, bronchoconstriction, and cigarette smoke on morphometric airway dimensions. $\mathcal{F}$ Appl Physiol 1988;64:913-9.

13 James AL, Hogg JC, Dunn LA, Paré PD. The use of the internal perimeter to compare airway size and to calculate smooth muscle shortening. Am Rev Respir Dis 1988;138:136-9.

14 James AL, Paré PD, Hogg JC. The mechanics of airway narrowing in asthma. Am Rev Respir Dis 1989;139:242-6.

15 Carroll N, Elliot J, Morton A, James A. The structure of large and small airways in nonfatal and fatal asthma. Am Rev Respir Dis 1993;147:405-10.

16 Kuwano K, Bosken CH, Paré PD, Bai TR, Wiggs BR, Hogg JC. Small airways dimensions in asthma and in chronic obstructive pulmonary disease. Am Rev Respir Dis 1993;148:1220-5.

17 Dunnill MS, Massarella GR, Anderson JA. A comparison of the quantitative anatomy of the bronchi in normal subjects, in status asthmaticus, in chronic bronchitis, and in emphysema. Thorax 1969;24:176-9.

18 Takizawa T, Thurlbeck WM. Muscle and mucous gland size in the major bronchi of patients with chronic bronchitis, asthma, and asthmatic bronchitis. Am Rev Respir Dis 1971;104:331-6.

19 Heard BE, Hossain S. Hyperplasia of bronchial smooth muscle in asthma. f Pathol 1972:110:319-1.

20 Hossain S. Quantitative measurements of bronchial muscle in men with asthma. Am Rev Respir Dis 1973;107:99-109.

21 Saetta M, Di Stefano A, Rosina C, Thiene G, Fabbri LM. Quantitative structural analysis of peripheral airways and arteries in sudden fatal asthma. Am Rev Respir Dis 1991;143:138-43.

22 Ebina M, Yaegashi H, Chiba R, Takahashi T, Motomiya M, Tanemura M. Hyperreactive site in the airway tree of asthmatic patients revealed by thickening of bronchial muscles: a morphometric study. Am Rev Respir Dis 1990;141:1327-32.

23 Ebina M, Takahashi T, Chiba T, Motomiya M. Cellular hypertrophy and hyperplasia of airway smooth muscles underlying bronchial asthma: a $3-$ D morphometric study. Am Rev Respir Dis 1993;148:720-6.

24 Glynn AA, Michaels L. Bronchial biopsy in chronic bronchitis and asthma Thorax 1960;15:142-53.

25 Paganin F, Trussard V, Seneterre E, Chanez P, Giron J, Godard P, et al. Chest radiography and high resolution computed tomography of the lungs in asthma. Am Rev Respir Dis 1992;146:1084-7.

26 Lynch DA, Newell JD, Tschomper BA, Cink TM, Newman LS, Bethel R. Uncomplicated asthma in adults: comparison of CT appearances of the lungs in asthmatic and healthy subjects. Radiology 1993;188:829-33.

27 Paganin F, Séneterre E, Chanez P, Daurés JP, Bruel JM, Michel FB, et al. Computed tomography of the lungs in asthma: influence of disease severity and etiology. Am F Respir Crit Care Med 1996;153:110-4.

28 Boulet L-P, Belanger M, Carrier G. Airway hyperresponsiveness and bronchial wall thickness in asthma with or without fixed airflow obstruction. Am F Respir Crit Care Med 1995;152:865-71.

29 Moreno RH, Hogg JC, Paré PD. Mechanics of airway narrowing. Am Rev Respir Dis 1986;133:1171-80.

30 Wiggs BR, Moreno R, Hogg JC, Hilliam C, Paré PD. A model of the mechanics of airway narrowing. F Appl Physiol 1990;69:849-60.

31 Wiggs BR, Bosken C, Paré PD, James A, Hogg JC. A model of airway narrowing in asthma and in chronic obstructive pulmonary disease. $\mathrm{Am}$ Rev Respir Dis 1992;145:1251-8.

32 Houston JC, de Navasquez S, Trounce JR. A clinical and pathological study of fatal cases of status asthmaticus. Thorax 1953;8:207-13.

33 Cardell BS, Pearson RSB. Death in asthmatics. Thorax 1959;14:341-52.

34 Dunnill MS. The pathology of asthma, with special reference to changes in the bronchial mucosa. F Clin Pathol 1960;13:27-33.

35 Messer JW, Peters GA, Bennett WA. Causes of death and pathologic findings in 304 cases of bronchial asthma. Dis Chest 1960;38:616-24.
36 Salvato G. Some histological changes in chronic bronchitis and asthma. Thorax 1968;23:168-72.

37 Beasley R, Roche WR, Roberts JA, Holgate ST. Cellular events in the bronchi in mild asthma and after bronchial provocation. Am Rev Respir Dis 1989;139:806-17.

38 Jeffery PK, Wardlaw AJ, Nelson FC, Collins JV, Kay AB. Bronchial biopsies in asthma: an ultrastructural, quantitative study and correlation with hyperreactivity. Am Rev Respir Dis 1989;140:1745-53.

39 Roche WR, Beasley R, Williams JH, Holgate ST. Subepithelial fibrosis in the bronchi of asthmatics. Lancet 1989;i:520-4.

40 McCarter JH, Vazquez JJ. The bronchial basement membrane in asthma. Arch Pathol 1966;82:328-35.

41 Molina C, Brun J, Coulet M, Betail G, Delage J. Immunopathology of the bronchial mucosa in "late-onset" asthma. Clin Allergy 1977;7:137-45.

42 Cutz E, Levison H, Cooper DM. Ultrastructure of airways in children with asthma. Histopathology 1978;2:407-21.

, Wilson J, Holgate ST, Roche WR. Myofibroblasts and subepithelial fibrosis in bronchial asthma. $A m \mathcal{F}$ Respir Cell Mol Biol 1990;3:507-11.

44 Hogg JC, Macklem PT, Thurlbeck WM. Site and nature of airway obstruction in chronic obstructive lung disease. $N$ Engl f Med 1968;278 1355-60.

45 Massagué J. The transforming growth factor- $\beta$ family. Annu Rev Cell Biol 1990;6:597-641.

46 Raines EW, Bowen-Pope DF, Ross R. Platelet-derived growth factor. In: Sporn $\mathrm{MB}$, Roberts $\mathrm{AB}$, ed. Handbook of experimental pharmacology. Peptide
growth factors and their receptors. Heidelberg: Springer-Verlag, 1990: $173-$ 262.

47 Burgess WH, Maciag T. The heparin-binding (fibroblast) growth factor family of proteins. Ann Rev Biochem 1989;58:575-606.

48 Vilcek J, Palombella VJ, Henrikson-DeStefano D, Swenson C, Feinman R, Hirai $M$, et al. Fibroblast growth enhancing activity of tumor necrosis factor and its relationship to other polypeptide growth factors. $\mathcal{F}$ Exp Med 1986;163:632-43.

49 Postlethwaite AE, Holness MA, Katai H, Raghow R. Human fibroblasts synthesize elevated levels of extracellular matrix proteins in response to interleukin 4. F Clin Invest 1992;90:1479-85.

50 Doherty AM. Endothelin: a new challenge. F Med Chem 1992;35:1493-508.

1 Panettieri RA, Vavdish PA, Kelly AM, Rubinstein NA, Kotlikoff MI. Histamine stimulates proliferation of airway smooth muscle and induces c-fos expression. Am f Physiol 1990;259:L365-71.

52 Ruoss SJ, Hartmann T, Caughey GH. Mast cell tryptase is a mitogen for cultured fibroblasts. $\mathcal{f}$ Clin Invest 1991;88:493-9.

53 Jarjour NN, Calhoun WJ, Schwartz LB, Busse WW. Elevated bronchoalveolar lavage fluid histamine levels in allergic asthmatics are associated with increased airway obstruction. Am Rev Respir Dis 1991;144:83-7.

54 Broide DH, Lotz M, Cuomo AJ, Coburn DA, Federman EC, Wasserman SI. Cytokines in symptomatic asthma airways. F Allergy Clin Immunol 1992;89:958-67.

55 Redington AE, Springall DR, Ghatei MA, Holgate ST, Polak JM, Howarth $\mathrm{PH}$. Endothelin in bronchoalveolar lavage fluid and its relation to airflow obstruction in asthma. Am ₹ Respir Crit Care Med 1995;151:1034-9.

56 Redington AE, Madden J, Djukanovic R, Holgate ST, Howarth PH. Transforming growth factor-beta levels in bronchoalveolar lavage fluid are increased in asthma. F Allergy Clin Immunol 1995;95:377 (abstract).

57 Redington AE, Madden J, Frew AJ, Djukanovic R, Roche WR, Holgate $\mathrm{ST}$, et al. Basic fibroblast growth factor in asthma: immunolocalization in bronchial biopsies and measurement in bronchoalveolar lavage fluid at baseline and following allergen challenge. Am f Respir Crit Care Med 1995, 151:A702 (abstract)

58 Haahtela T, Järvinen M, Kava T, Kiviranta K, Koskinen S, Lehtonen K, et al. Effects of reducing or discontinuing inhaled budesonide in patients with mild asthma. N Engl F Med 1994;331:700-5.

59 Saetta M, DiStefano A, Maestrelli P, DeMarzo N, Milani GF, Pivirotto F, et al. Airway mucosal inflammation in occupational asthma induced by toluene diisocyanate. Am Rev Respir Dis 1992;145:160-8.

60 Ulrik CS, Lange P. Decline of lung function in adults with bronchial asthma. Am $\mathcal{F}$ Respir Crit Care Med 1994;150:629-34.

61 Trigg CJ, Manolitsas ND, Wang J, Calderón M, McAulay A, Jordan SE, et al. Placebo-controlled immunopathologic study of four months on inhaled corticosteroids in asthma. Am $\mathcal{F}$ Respir Crit Care Med 1994;150: $17-22$.

62 Djukanovic R, Wilson JW, Britten KM, Wilson SJ, Walls AF, Roche WR, et al. Effect of an inhaled corticosteroid on airway inflammation and symptoms in asthma. Am Rev Respir Dis 1992;145:669-74.

63 Jeffery PK, Godfrey RW, Ädelroth E, Nelson F, Rogers A, Johansson S-A. Effects of treatment on airway inflammation and thickening of basement membrane reticular collagen in asthma: a quantitative light and electron microscopic study. Am Rev Respir Dis 1992;145:890-9. 